\title{
Citotoxicity of nonlatex elastomeric ligatures of orthodontic use
}

\author{
Rogério Lacerda-Santos ${ }^{1,}$ Alane Sonally Benício do Nascimento ${ }^{1}$, \\ Allana Roberta Bandeira Pereira ${ }^{1}$, Paulyana Pryscilla de Melo Freire ${ }^{1}$, \\ Matheus Melo Pithon ${ }^{2}$, Maria Teresa Villela Romanos ${ }^{3}$
}

\footnotetext{
${ }^{1}$ Department of Orthodontics, Federal University of Campina Grande - UFCG, Av. dos Universitários, s/n, Rodovia Patos/Teixeira, Km1, Santa Cecília, Cep: 58700-970, Patos, Paraíba, Brazil. e-mail: lacerdaorto@ hotmail.com, lacerdaorto@gmail.com

${ }^{2}$ Department of Orthodontics, State University of Southwest Bahia - UESB, Rua José Moreira Sobrinho, S/N, Jequiezinho, Cep: 45206-190, Jequié, Bahia, Brazil. e-mail: matheuspithon@ gmail.com

${ }^{3}$ Department of Virology, Federal University of Rio de Janeiro - UFRJ, Av. Professor Rodolpho Paulo Rocco, 325, Ilha do Fundão, Cep: 21944-970, Rio de Janeiro, Rio de Janeiro, Brazil. e-mail: teresaromanos@ micro.ufrj.br
}

\section{ABSTRACT}

The aim of this study is to evaluate cytotoxicity between polyurethane and non-latex orthodontic elastomeric ligatures. Seven elastomeric ligatures of black-coloured from different manufactures ( 3 non-latex, 3 polyurethane and 1 latex) were divided into 7 groups of 10 elastics each: Group UK (nonlatex, 3M Unitek), Group TP (nonlatex, TP Orthodontics), Group AO (nonlatex, American Orthodontics), Group O (Polyurethane, OrthoSource), Group M (Polyurethane, Morelli), Group TD (Polyurethane, Tecnident) and Group TC (latex Control, TP Orthodontics). The cytotoxicity essay was performed using cell cultures (L-929 line cells, mouse fibroblast) that were submitted to the cell viability test with neutral red (“dye-uptake") at 1, 2, 3, 7 and 28 days. Analysis of variance (ANOVA) with 1-way analysis followed by the Tukey post hoc test were employed $(\mathrm{p}<.05)$. The results showed no statistically significant differences between Groups UK, TP and AO in all experimental times $(p>.05)$. There was a statistically differences $(p<.05)$ between the viability cell of Groups UK, TP and AO with the Groups O, M, TD and TC at 1, 2, 3 and 7 days. There was no statistically differences ( $p>.05)$ between the groups $\mathrm{O}, \mathrm{M}$ and TD at in all experimental times. It can be concluded that the nonlatex elastomeric ligatures of Unitek, TP Orthodontics, and American Orthodontics showed higher cell viability compared to others ligatures.

Keywords: Cytotoxicity, Elastomers, Cell culture.

\section{INTRODUCTION}

The latex because of its applicability in the health area has been the subject of many studies [1- $\underline{5}$ ]. In dentistry, specifically in orthodontics, elastomers are used to supply force to move the teeth, are commonly used in orthodontic treatment []].

However, the protein content of latex is a known allergen. Studies [ $\underline{3}-\underline{4}, \underline{7}]$ have reported a prevalence of latex sensitization of $4 \%$ [7] to $17 \%[\underline{3}, \underline{4}]$ of the general population was reported to be positive to the natural rubber allergy by serologic testing with latex immunoglobulin E antibodies [7].

Because latex allergy is prevalent of among occupationally exposed groups and patients, the need of alternatives, as elastomers of polyurethane and nonlatex, is increasing.

But little is known if polyurethane and nonlatex elastics if are inert to oral mucosal cells [1- $\underline{6}$ ]. For other side, L929 mouse fibroblasts [8], have been shown to behave similarly to primary human gingival fibroblasts and, therefore, are a suitable in-vitro model to the toxicity test [9-12]. Taken in conjunction, these findings are aligned with the notion that the orthodontic elastics citotoxicity may influence their clinical performance $[\underline{4}, \underline{13}]$ with regard to tissue biocompatibility. In this line, the objective of the present in vitro study was to test the cytotoxicity of polyurethane and nonlatex orthodontic elastomeric ligatures of different manufactures. 


\section{MATERIAL AND METHODS}

Esta Black-coloured orthodontic elastomeric ligatures from 6 different manufacturers were selected for cytotoxicity study, being: three of nonlatex, three containing polyurethane and one of latex (Table 1). The samples were divided into 7 groups of 10 elastics each: Group UK (nonlatex, 3M Unitek, Monrovia, California, USA), Group TP (nonlatex, TP Orthodontics, Lodi, California, USA), Group AO (nonlatex, American Orthodontics, Sheboygan, Wisconsin, USA), Group O (Polyurethane, OrthoSource, North Hollywood, CA, USA), Group M (Polyurethane, Morelli, Sorocaba, São Paulo, Brazil), Group TD (Polyurethane, Tecnident, São Carlos, São Paulo, Brazil) and Group TC (latex - Control, TP Orthodontics, Lodi, California, USA).

Table 1: Experimental and control groups used for the assays.

\begin{tabular}{ccccc}
\hline Groups & Trademark & $\begin{array}{c}\text { Main } \\
\text { Composition }\end{array}$ & Colour & Reference number \\
\hline UK & Unitek & Nonlatex & Black & $406-882$ \\
TP & TP Orthodontics & Nonlatex & Black & $383-927$ \\
AO & American O. & Nonlatex & Black & $854-273$ \\
O & OrthoSource & Polyurethane & Black & $0-0424-161$ \\
M & Morelli & Polyurethane & Black & $60-06-110$ \\
TD & Tecnident & Polyurethane & Black & $407-001$ \\
TC & TP Orthodontics & latex natural & Black & $361-092$ \\
C+ & Tween 80 (Polyoxyethylene-20-sorbitan, Sigma, St. Louis, Missouri, USA) \\
C- & PBS solution (phosphate-buffered saline, Cultilab, Campinas, SP, Brazil) \\
CC & \multicolumn{2}{c}{ cell control ( L-929 line cells, ATCC, Rockville, MD, USA) } \\
\hline
\end{tabular}

All samples had recent manufacturing dates, were from the same production lot and came in sealed plastic packages. The superficial powder coating of the elastomeric ligatures was removed, in which, all elastics were washed for 15 seconds with current deionized water by using a Milli-Q purification system (Millipore, Bedford, MA, USA) and dried lightly with absorbent paper. Before testing all elastomeric ligatures were sterilized by exposure to ultraviolet light (Labconco, Kansas, Missouri, USA) for 30 minutes [14-15].

The cell culture model used was the monolayer containing L-929 line cells (American Type Culture Collection - ATCC, Rockville, MD, USA) maintained in Eagles' minimum essential medium (Cultilab, Campinas, Brazil) by adding $0.03 \mathrm{mg} / \mathrm{ml}$ of glutamine, $50 \mu \mathrm{g} / \mathrm{ml}$ of garamicine, $2.5 \mathrm{mg} / \mathrm{ml}$ of fungizone, $0.25 \%$ sodium bicarbonate solution, $10 \mathrm{mM}$ of HEPES, and $10 \%$ bovine fetal serum for growth medium. Next, the cell culture medium was incubated at $37^{\circ} \mathrm{C}$ for 48 hours.

To verify the cell response in extreme situations, three additional groups were included in the study: Group CC (cell control), consisting of L-929 cells not exposed to supernatants from the elastomeric ligatures; Group C+ (positive control), consisting of Tween 80 (Polyoxyethylene-20-sorbitan, Sigma, St. Louis, Missouri, USA); Group C- (negative control), consisting of phosphate-buffered saline (PBS) solution (Table 1). The positive and negative controls were incubated in MEM maintenance medium (Eagles' minimum essential medium) for 1, 2, 3, 7 and 28 days and the extracted elutes were added to L-929 line cells incubated in the growth medium.

The cytotoxicity of these orthodontic elastics was determined through the dye-uptake technique [16], which is based on the neutral red absorption by living cells. How these chain elastics are usually maintained in the oral cavity for up to 4 weeks, since patients wearing fixed appliances usually visit the orthodontist once a month, the periods of time: $1,2,3,7$, and 28 days were evaluated in this study. These experimental periods represent the time maintenance under cell culture conditions before removal of the ligatures.

\subsection{Dye-uptake}

Volumes of $100 \mu 1$ of L-929 cells were distributed in triplicate for each specimen tested into 96-well microplates. After 48 hours, the growth medium was replaced with $100 \mu \mathrm{l}$ of Eagles' minimum essential medium (MEM) obtained following incubation in the different types of elastomeric ligatures at 1,2, 3, 7 and 28 days. 
Eagles' minimum essential medium was employed because it is the same type of material used for cell maintenance, thus not influencing the results.

After 24 hours of incubation, $100 \mu \mathrm{l}$ of 0.01 per cent neutral red dye (Sigma, St. Louis, Missouri, USA) was added to each well in the microplates and incubated for 3 hours at $37^{\circ} \mathrm{C}$. Following this period of time, $100 \mu \mathrm{l}$ of 4 per cent formaldehyde solution in PBS (130 mmol of NaCl; $2 \mathrm{mmol}$ of $\mathrm{KCl} ; 6 \mathrm{mmol}$ of $\mathrm{Na}_{2} \mathrm{HPO}_{4}$ $2 \mathrm{H}_{2} \mathrm{O} ; 1 \mathrm{mmol}$ of $\mathrm{K}_{2} \mathrm{HPO}_{4} 1 \mathrm{mmol} ; \mathrm{pH}$ 7.2) were added to each well to promote cell attachment to the plate. After 5 minutes, $100 \mu \mathrm{l}$ of 1 per cent acetic acid and 50 per cent methanol were added in order to remove the dye not taken up by the cells. After 20 minutes, a spectrophotometer (BioTek, Winooski, Vermont) set at a wavelength of $492 \mathrm{~nm}$ was used to determine the dye taken up by the cells. Because elastomeric ligatures can be in the oral cavity for up to 4 weeks, cell viability was determined after exposure to MEM in which the elastics had been incubated for 1, 2, 3, 7 and 28 days. The cytotoxicity of the materials was determined according to ISO 10993-5 [17] for evaluation and standardization.

For ranking the citoxicity, a post hoc comparison was performed [18-19]. Statistical calculations were performed with 1-way analysis of variance (ANOVA) followed by the Tukey post hoc test. $P$ values less than .05 were considered to indicate significant differences. Each culture well was considered an individual sample.

\section{RESULTS}

There were a statistically significant difference $(\mathrm{p}=.00)$ between the viability of the cells in Group CC (Figure 1A) and all other groups at 1, 2, 3, 7 and 28 days. Nor were there any statistically significant differences (p>.05) between the viability of the cells in Groups UK, TP and AO (Figure 1B) or between Groups O, M and TD (Figure1C) at 1, 2, 3, 7 and 28 days (Table 2 and Figure 2). The Group TC showed statistical difference with Groups M, TD at 1 day, Groups O, M at 2 and 7 days, and with Groups O, M, TD at 3 days $(\mathrm{p}<0.05)$. There were decrease viable cells at 1 and 2 days of all the Groups compared to the other experimental times (Table 2 and Figure 2). However, with 28 days the elastomeric ligatures evaluated showed similar cell viability.

Table 2: Descriptive statistics for optical density of elastomeric ligatures at 1 to 28 days.

\begin{tabular}{|c|c|c|c|c|c|c|c|c|c|c|c|c|c|c|c|}
\hline \multirow[b]{2}{*}{ G } & \multicolumn{3}{|c|}{ Time (1 day) } & \multicolumn{3}{|c|}{ Time (2 days) } & \multicolumn{3}{|c|}{ Time (3 days) } & \multicolumn{3}{|c|}{ Time (7 days) } & \multicolumn{3}{|c|}{ Time (28 days) } \\
\hline & M & SD & $\begin{array}{l}\text { VC } \\
(\%)\end{array}$ & M & SD & $\begin{array}{l}\text { VC } \\
(\%)\end{array}$ & $\mathbf{M}$ & SD & $\begin{array}{l}\text { VC } \\
(\%)\end{array}$ & $\mathbf{M}$ & SD & $\begin{array}{l}\text { VC } \\
(\%)\end{array}$ & $\mathbf{M}$ & SD & $\begin{array}{l}\text { VC } \\
(\%)\end{array}$ \\
\hline $\mathrm{CC}$ & $.930^{\mathrm{a}}$ & .035 & 100.0 & $.905^{\mathrm{a}}$ & .044 & 100.0 & $.816^{\mathrm{a}}$ & .049 & 100.0 & $.695^{\mathrm{a}}$ & .041 & 100.0 & $.817^{\mathrm{a}}$ & .047 & 100.0 \\
\hline C- & .892 & .037 & 96.0 & .882 & .042 & 97.5 & .802 & .040 & 98.4 & .670 & .027 & 96.5 & .768 & .042 & 94.1 \\
\hline $\mathrm{C}+$ & .071 & .008 & 7.70 & .084 & .011 & 9.30 & .071 & .009 & 8.80 & .075 & .009 & 10.8 & .078 & .010 & 9.60 \\
\hline UK & $.824^{\mathrm{b}}$ & .039 & 88.7 & $.795^{\mathrm{b}}$ & .033 & 87.9 & $.743^{\mathrm{b}}$ & .037 & 91.1 & $.646^{\mathrm{b}}$ & .045 & 93.0 & $.758^{\mathrm{b}}$ & .046 & 93.9 \\
\hline TP & $.828^{\mathrm{b}}$ & .030 & 89.1 & $.814^{\mathrm{b}}$ & .043 & 90.0 & $.750^{\mathrm{b}}$ & .036 & 92.0 & $.647^{\mathrm{b}}$ & .029 & 93.2 & $.768^{\mathrm{b}}$ & .032 & 94.1 \\
\hline AO & $.813^{b}$ & .047 & 87.5 & $.781^{b}$ & .040 & 86.3 & $.736^{\mathrm{b}}$ & .027 & 90.3 & $.632^{b c}$ & .034 & 91.0 & $.759^{\mathrm{bc}}$ & .044 & 93.0 \\
\hline O & $.728^{\mathrm{cd}}$ & .046 & 77.3 & $.714^{\mathrm{c}}$ & .044 & 75.2 & $.680^{\mathrm{c}}$ & .038 & 83.4 & $.626^{\mathrm{c}}$ & .032 & 90.1 & $.744^{b c}$ & .038 & 91.1 \\
\hline M & $.740^{c}$ & .030 & 79.6 & $.685^{\mathrm{c}}$ & .036 & 75.8 & $.700^{\mathrm{c}}$ & .042 & 85.9 & $.625^{\mathrm{c}}$ & .045 & 90.0 & $.743^{\mathrm{bc}}$ & .048 & 91.0 \\
\hline TD & $.744^{\mathrm{c}}$ & .038 & 79.0 & $.663^{\text {cd }}$ & .035 & 73.3 & $.686^{\mathrm{c}}$ & .043 & 84.1 & $.622^{\mathrm{cd}}$ & .039 & 89.5 & $.736^{\mathrm{bc}}$ & .037 & 90.2 \\
\hline TC & $.698^{\mathrm{d}}$ & .030 & 74.2 & $.642^{\mathrm{d}}$ & .026 & 71.0 & $.645^{\mathrm{d}}$ & .027 & 79.1 & $.602^{\mathrm{d}}$ & .028 & 86.7 & $.726^{\mathrm{c}}$ & .020 & 89.0 \\
\hline
\end{tabular}

$\mathrm{N}=10$. Analysis of variance ANOVA and Tu.key's test were employed $(\mathrm{p}<.05)$. Values followed by same letters are not significantly different ( $>>$.05) for the same time. G: Groups. M: Mean. SD: standard deviation. VC: Viable Cells.

At 24 hours the percentage of viable cells varied between 89.1 per cent in Group TP non-latex elastomeric ligatures, to 74.2 per cent in Group TC latex elastomeric ligatures. These percentages of viable cells decreased slightly over the following 24 hours in all Groups. Then, there was an increased continued in all Groups between Days 3 and 28 (Table 2 and Figure 2). 

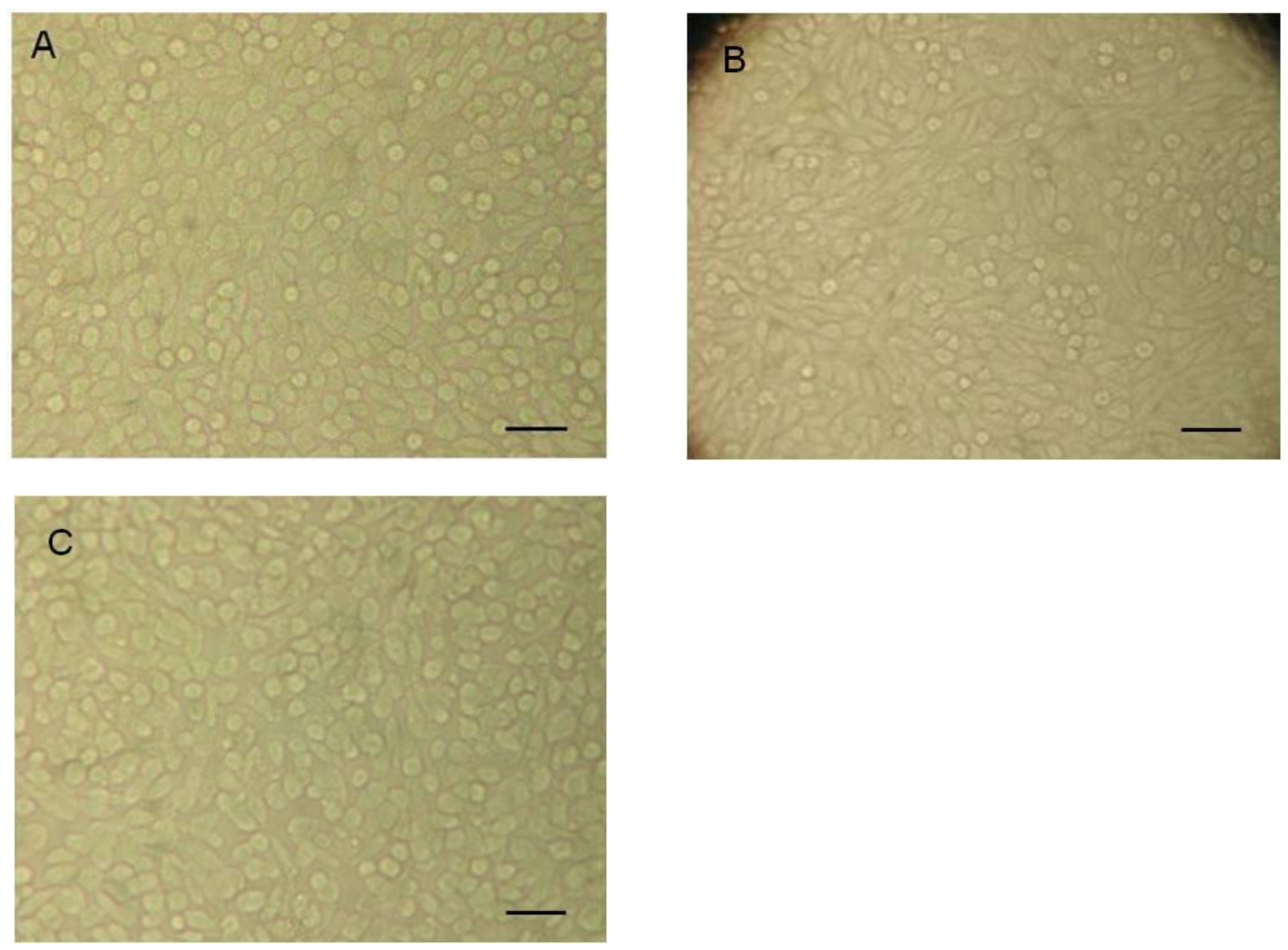

Figure 1: Cell aspect. A) cell control; B) group AO (American Orthodontics) at 2 days; C) group TD (Tecnident) at 2 days. $\mathrm{Bar}=50 \mu \mathrm{m}$.

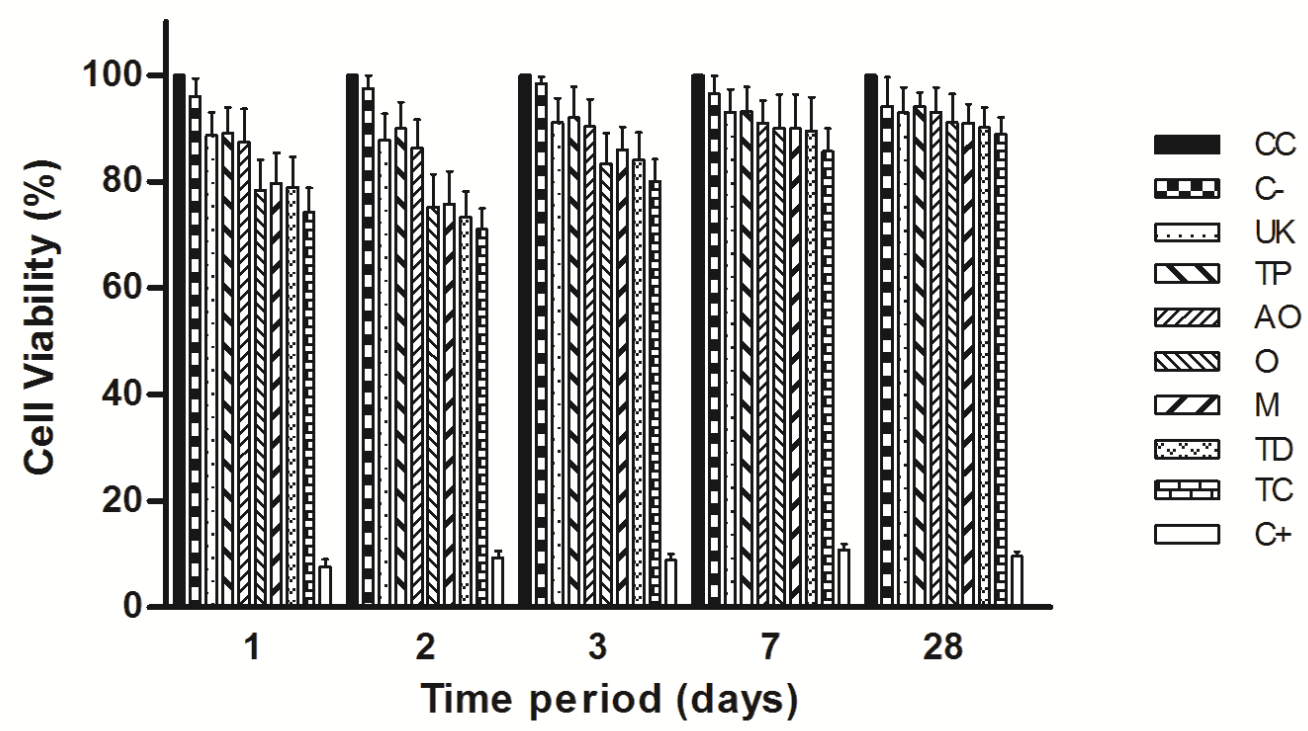

Figure 2: Percentage viability of tested elastomeric ligatures obtained by spectrophotometry. 


\section{DISCUSSION}

Although cytotoxicity and allergies to dental latex materials were mostly reported for latex gloves [20-21]. Current studies $[1,15]$ has shown the biological behavior of orthodontic elastomeric ligatures through of cytoxicity test because orthodontic elastics are kept in the closed space of the oral cavity for several days.

The cell culture model used in the present study was the monolayer [22]. This model was used together with the dye-uptake technique [18] by spectrophotometry.

Spectrophotometric essay allows rapid and reliable evidence for cell viability to be obtained based on the use of vital stain incorporated by viable cells [23-24]. Dead or damaged cells cannot incorporate vital stain, thus not being recognized on optical reading. Therefore, spectrophotometry does not allow dead cells to be distinguished from the damaged ones [17].

Although latex rubber has shown biocompatibility as a dental material, many cytotoxic factors have been reported. Conservants such as sulphur and zinc oxide as well as antioxidants such as di-thio-carbohydrates, $\mathrm{N}$-nitrosodibutylamine, and $\mathrm{N}$-nitrosopiperidine are all known to be cytotoxic substances [5].

The most serious consequence of natural rubber latex allergy commonly takes place during the mucosal absorption of natural rubber latex proteins during intraoperative medical or dental procedures when health care workers or others already sensitized become patients [25]. This latex allergy occurs because natural latex contains many kinds of proteins, and the glove's powder coating functions as a carrier of those latex proteins.

As an alternative to latex, front the reports of latex allergy [26] and their cytotoxic character in literature [16-17], this study evaluated the cytotoxicity of polyurethane and nonlatex Orthodontic elastomeric ligatures of different manufactures.

We have assessed the Unitek, TP Orthodontics and American Orthodontics, nonlatex elastomeric ligatures and it was observed that this material induced a lesser amount of cell lysis compared the polyurethane elastomeric ligatures. The great [15] danger is that, potentially cytotoxic intra-oral elastics could release substances that might be ingested by the patient over time, thus causing diseases resulting from a cumulative effect.

The latex ligature tested in this study demonstrated the lowest values of cell viability in all experimental times, result of the release of latex proteins and stabilising substances with cytotoxic potential [1], although a similar performance was demonstrated between the latex ligature and polyurethane ligatures. Polyurethane elastomeric ligatures from OrthoSource, Morelli, and Tecnident, trademarks induced a greater amount of cell lysis at 24 and 48 hours, suggesting a greater release of toxic ingredients at 48 hours, due to a possible of polyurethane degradation and release of cytotoxic components, which was shown on days 1 and 2 , and decreased on days 3, 7 and 28. However, all elastomeric ligatures were found to be biocompatible after the $3^{\text {rd }}$ experimental day. Study [27] that examined whether the dyes used in manufacturing colored latex bands could have any toxic effects, showed that these colourants exhibited low toxicity, clinically, however, this effect is harmless, confirming the findings of this study.

However, there have been a few reports about the cytotoxicity of nonlatex elastics. Byproducts produced during the condensation procedure of polymerization have been reported to be cytotoxic [28]. However, these byproducts decrease in cytotoxicity after 1 hour and have a very low cytotoxic effect on intraoral soft tissues [29]. The safety biocompatibility of nonlatex elastics has been well proved through the use of mouth guards in dentistry [30]. In this study, all elastomeric ligatures evaluated showed cell viability, over of $70 \%$ in all experimental periods, that allowing affirm the high viability of the evaluated materials.

The materials described by the manufacturer as nonlatex have linear or cross-linked polymer composition, which are thermoplastic or thermoset materials. In this study, the nonlatex elastomeric ligatures presented better performance compared to the announced-polyurethane ligatures, suggesting that the process of industrialization and/or the presence of stabilizing substances noncytotoxic in the composition these nonlatex elastics, are responsible for different behavior these elastics, despite being reported by manufacturers the atoxicity of polyurethane materials. However, the tested elastomers have been shown to be a safe alternative for clinical use in individuals already sensitized or in potential to contact with rubber latex.

\section{CONCLUSION}

It can be concluded that, the nonlatex ligatures of Unitek, TP Orthodontics and American Orthodontics trademark induced a lesser amount of cell lysis compared to Orthosource, Morelli and Tecnident polyurethane ligatures. The latex elastomeric ligature caused the greatest amount of cell lysis, however, all ligatures were clinically biocompatible, starting from the 7 th day. 


\section{BIBLIOGRAPHY}

[1] PITHON, M. M., SANTOS, R. L., JUDICE, R. L. P., et al. Evaluation of the cytotoxicity of elastomeric ligatures after sterilisation with 0.25\% peracetic acid, Aust Orthod J, v.29, n.2, p.139-144, Nov. 2013.

[2] WAKELIN, S. H., WHITE, I. R. "Natural rubber latex allergy", Clin Exp Dermatol., v.24, n. 13, p.245248, Sept. 1999.

[3] TOMAZIC, V. J., WITHROW, T. J., FISHER, B. R., et al. "Latex-associated allergies and anaphylactic reactions", Clin Immunol Immunopathol, v.64, n.31, pp.89-97, Oct. 1992.

[4] TURJANMAA, K., ALENIUS, H., MAKINEN-KILJUNEN, S., et al. "Natural rubber latex allergy", Allergy, v.51, n.35, pp.593-602, Dec. 1996.

[5] FIDDLER, W., PENSABENE, J., SPHON, J., et al. "Nitrosamines in rubber bands used for orthodontic purposes", Food Chem Toxicol, v.30, n.22, pp.325-326, Aug. 1992.

[6] HWANG, C. J., CHA, J. Y. "Mechanical and biological comparison of latex and silicone rubber bands", Am J Orthod Dentofacial Orthop, v.124, n.19, pp.379-386, Apr. 2003.

[7] MAKINEN-KILJUNEN, S. "Banana allergy in patients with immediatetype sensitivity to natural latex: characterization of cross-reacting antibodies and allergens", Allergy Clin Immunol., v.93, n.8, p.990-996, Sept. 1994.

[8] MIRANDA, R. B., FIDEL, S. R., BOLLER, M. A. "L929 cell response to root perforation repair cements: an in vitro cytotoxicity assay", Braz Dent J., v.20, n.6, pp.22-26, Apr. 2009.

[9] D'ANTO, V., SPAGNUOLO, G., SCHWEIKL, H., RENGO, S., AMBROSIO, L., MARTINA, R., et al. "Effect of N-acetyl cysteine on orthodontic primers cytotoxicity", Dent Mater., v.27, n.8, pp.180-186, Jun. 2011.

[10] HAFEZ, H. S., SELIM, E. M., KAMEL, E. I. D., et al. "Cytotoxicity, genotoxicity, and metal release in patients with fixed orthodontic appliances: A longitudinal in-vivo study". Am J Orthod Dentofacial Orthop. v.140, n.20, p.298-308, Oct. 2011.

[11] LIMBERGER, K. M., WESTPHALEN, G. H., MENEZES, L. M., MEDINA-SILVA, R. "Cytotoxicity of orthodontic materials assessed by survival tests in Saccharomyces cerevisiae", Dent Mater., v.27, n.10, pp.81-86, Febr. 2011.

[12] YEAP, S. K., OMAR, A. R., ALI, A. M., et al. "Immunomodulatory Effect of Rhaphidophora korthalsii on Natural Killer Cell Cytotoxicity", Evid Based Complement Alternat Med., 2012

[13] NEIBURGER, E. J. "A case of possible latex allergy", J Clin Orthod., v.25, n.2, p.559-560, Feb. 1991.

[14] REMATOSO, L., SANTOS, R. L., CUNHA, T. M. A., et al. In vitro cytotoxicity of self-curing acrylic resins of different colors, Dental Press J Orthod., v. 19, n.4, pp. 66-70, Jul-Aug. 2014.

[15] DOS SANTOS, R. L., PITHON, M. M., FREIRE, P. P. D. M., et al. "In Vitro Study of Cytotoxicity of Orthodontic Elastomeric Ligatures", Mater Res., v.15, n.4, pp.657-661, May. 2012.

[16] NEYNDORFF, H. C., BARTEL, D. L., TUFARO, F., et al., "Development of a model to demonstrate photosensitizer-mediated viral inactivation in blood", Transfusion, v.30, n.4, pp.485-490, Jun. 1990.

[17] ISO 10993-5, Biological Evaluation of Medical Devices. Part 5. Test for In Vitro Cytotoxicity, 2009.

[18] EINOT, I., GABRIEL, K. R. "A study of powers of several methods of multiple comparisons", J Am Stat Assoc,. v.70, n.7, p.574-583, Oct. 1975.

[19] WELSCH, R. E. "Stepwise multiple comparison procedures", J Am Stat Assoc., v.72, n.8, pp. 354-359, Dec. 1977.

[20] NATTRASS, C., IRELAND, A. J., LOVELL, C. R. "Latex allergy in an orthognathic patient and implications for clinical management", Br J Oral Maxillofac Surg., v.7, n.4, p.11-13, Nov. 1999.

[21] NACEY, J. N., DELAHUNT, B. "Toxicity study of first and second generation hydrogel coated latex urinary catheters", Br J Urol., v. 67, n. 6, pp.314-6, Apr. 1991.

[22] TOMAKIDI, P., KOKE, U., KERN, R., et al. "Assessment of acute cyto- and genotoxicity of corrosion eluates obtained from orthodontic materials using monolayer cultures of immortalized human gingival keratinocytes", J Orofac Orthop., v.61, n.4, p.2-19, Feb. 2000.

[23] SANTOS, R. L., PITHON, M. M., ROMANOS, M. T. V. "The effect of different pH levels on conventional vs. super-force chain elastics". Mater Res. v.15, n.6, p.1-6, Sep. 2012. 
[24] SANTOS, R. L., PITHON, M. M., PEREIRA, A. R. B., et al. "Evaluation of the cytotoxicity of polyurethane and non-latex orthodontic chain elastics", Materia, v.17, n.1, pp.939-945, Jan. 2012.

[25] SUSSMAN, G. L., BEEZHOLD, D. H., LISS, G. "Latex allergy: historical perspective", Methods, v.27, n.6, pp.3-9, Febr. 2002.

[26] SNYDER, H. A., SETTLE, S. "The rise in latex allergy: implications for the dentist", J Am Dent Assoc., v.125, n.8, pp.1089-1097, Oct.1994

[27] HOLMES, J., BARKER, M. K., WALLEY, E. K., et al., "Cytotoxicity of orthodontic elastics", Am J Orthod Dentofacial Orthop., v.104, n.4, pp.188-191, Jun.1993.

[28] CIAPETTI, G., GRANCHI, D., STEA, S. "Cytotoxicity testing of materials with limited in vivo exposure is affected by the duration of cell-material contact", J Biomed Mater Res., v.15, n.4, pp.485-90, Nov. 1998.

[29] POLYZOIS, G. L., HENSTEN-PETTERSEN, A. "An assessment of the physical properties and biocompatibility of three silicone elastomers", J Prosthet Dent., v.71, n.8, pp.500-504, Dec. 1994.

[30] CHAUVEL-LEBRET, D. J., PELLEN-MUSSI, P. "Evaluation of the in vitro biocompatibility of various elastomers", Biomaterials, v. 20, n.6, pp.291-9, Feb. 1991. 